\title{
Selectivity of ligand binding to opioid receptors in brain membranes from the rat, monkey and guinea pig
}

\author{
Mary J. Clark, Bruce D. Carter and Fedor Medzihradsky * \\ Departments of Biological Chemistry and Pharmacologv, The University of Michigan Medical School, Ann Arbor, MI 48109, U.S.A.
}

Received 8 December 1987, accepted 22 December 1987

Conditions for the equilibrium binding to opioid receptor of $\left[{ }^{3} \mathrm{H}\left[\right.\right.$ sufentanil ( $\mu$ selective), $\left[{ }^{3} \mathrm{H}\right]\left[\mathrm{D}-\mathrm{Pen}{ }^{2}\right.$, D-Pen $\left.{ }^{5}\right] \mathrm{en}$ kephalin ( $\delta$ selective), and $\left[{ }^{3} \mathrm{H}\right] \mathrm{U} 69,593$ ( $\kappa$ selective) were established in membranes from rat brain cerebrum, monkey cortex, or guinea pig cerebellum. The selectivity index of various opioid alkaloids and peptides in binding to the $\mu, \delta$, or $\kappa$ opioid receptors was expressed as the ratio of their $\mathrm{EC}_{50}$ values in displacing two selective radiolabeled ligands: $\left[{ }^{3} \mathrm{H}\right]$ sufentanil $/\left[{ }^{3} \mathrm{H}\right]\left(\mathrm{D}-\mathrm{Pen}^{2}, \mathrm{D}-\mathrm{Pen}^{5}\right.$ )enkephalin (selectivity: $\mu / \delta$ ), $\left[{ }^{3} \mathrm{H}\right]$ sufentanil $/\left[{ }^{3} \mathrm{H}\right] \mathrm{U} 69,593$ (selectivity: $\mu / \kappa$ ), or $\left[{ }^{3} \mathrm{H}\right]\left[\mathrm{D}-\mathrm{Pen}^{2}, \mathrm{D}-\mathrm{Pen}^{5}\right]$ enkephalin $/\left[{ }^{3} \mathrm{H}\right] \mathrm{U} 69,593$ (selectivity: $\delta / \kappa$ ). High resolution in binding selectivity was observed: in rat brain the $\mu / \delta$ selectivity for Tyr-D-Ala-Gly-(Me)Phe-Gly-ol and sufentanil were 0.02 and 0.03 , whereas for $\left[D-P^{2}{ }^{2}\right.$,D-Pen ${ }^{5}$ enkephalin and ICI 174,864 they were 1200 and 998. Compared to $\mu$ opiates, the specific binding of $\delta$ and $\kappa$ agonists was less sensitive to sodium. The results describe a routinely applicable methodological approach for the assessment of selective ligand binding to the $\mu, \delta$ and $\kappa$ opioid receptors in rodent and monkey brain membranes.

Opioid binding selectivity; Brain membranes; $\left[{ }^{3} \mathrm{H}\right]$ Sufentanil; $\left[{ }^{3} \mathrm{H}\right]\left[\mathrm{D}-\mathrm{Pen}^{2}, \mathrm{D}-\mathrm{Pen}^{5}\right]$ enkephalin; $\left[{ }^{3} \mathrm{H}\right]$ U69,593; (Multiple opioid receptors)

\section{Introduction}

Characterization of opioid receptor heterogeneity depends upon the availability of ligands with high selectivity toward the $\mu, \delta$ and $\kappa$ sites. Indeed, for a considerable time after the concept of multiple opioid receptors was introduced (Martin et al., 1976), progress in this field was hampered due to marginal selectivity of the then available opiates. Moreover, the use of opiates with crossrecognition at more than one receptor type has caused misinterpretations and disputes. A perti-

\footnotetext{
* To whom all correspondence should be addressed: Department of Biological Chemistry, M6440 Medical Science Building I, The University of Michigan Medical School, Ann Arbor, Michigan 48109, U.S.A.
}

nent example is the benzomorphan derivative ethylketocyclazocine, included in numerous earlier studies as a $\kappa$ agonist. Binding studies with the radiolabeled form of this opiate have resulted in equivocal conclusions as to the existence of separate $\kappa$ receptor sites (Hiller and Simon, 1979; Chang et al., 1980; Fischel and Medzihradsky, 1981; Garzon et al., 1984). More recently, it was shown that this compound binds with appreciable affinities to all three, $\mu, \delta$ and $\kappa$ receptors in brain membranes from the rat (Gillan and Kosterlitz, 1982; Fischel and Medzihradsky, 1986) and guinea pig (James and Goldstein, 1984).

Extensive information on the receptor binding of various opiates, as they became available over the years, was provided by Kosterlitz and coworkers. Facing the lack of selective radiolabeled primary ligands, these authors used an excess of 
unlabeled selective opiates to block the unwanted binding component of the radioligand in competitive displacement assays (Gillan and Kosterlitz, 1982: Corbett et al., 1984). Another approach to gain specificity of opiate binding in membrane preparations is the selective alkylation of opioid receptors, either by the direct or protective approach (James and Goldstein, 1984; Takemori and Portoghese, 1985; Clark and Medzihradsky, 1987). Ultimately, in such treated membranes containing only one type of functional opioid receptor any nonselective radiolabeled opiate, such as $\left[{ }^{3} \mathrm{H}\right]$ etorphine, can serve as a primary ligand to study the selectivity of other opiates (Medzihradsky, 1987). However, successful alkylation still depends on the availability of selective irreversible and/or reversible ligands. Nonetheless, using this approach the binding selectivity of various opiates in guinea pig brain membranes was described, although the authors noted methodological limitations imposed by the approach (James and Goldstein, 1984). The binding selectivity of opiates can also be studied in tissues specific for one type of opioid receptor, e.g., the $\kappa$ opioid receptor in guinea pig cerebellum (Robson et al., 1984; Clark et al., 1986).

In this paper we report the use of the recently available highly selective radiolabeled ligands $\left[{ }^{3} \mathrm{H}\right]$ sufentanil, $\left[{ }^{3} \mathrm{H}\right]\left(\mathrm{D}-\mathrm{Pen}^{2}, \mathrm{D}-\mathrm{Pen}^{5}\right)$ enkephalin, and $\left[{ }^{3} \mathrm{H}\right] \cup 69,593$ to resolve and quantitate the binding of opiates to the $\mu, \delta$, and $\kappa$ receptors in unaltered brain membranes. In developing the binding assays, we have placed special emphasis on fulfilling the criteria essential for characterizing ligand-receptor interactions at equilibrium. Applying the assays, we have determined the binding selectivity of 15 frequently used opiates. The results contribute to the characterization of the tested compounds and, concurrently, the obtained $\mathrm{EC}_{50}$ values serve as pertinent references to evaluate the binding of novel opiates. While all the compounds were studied in rat brain membranes, the binding of selected opiates was also determined in membranes from monkey cortex, a tissue containing $\mu, \delta$, and $\kappa$ opioid receptors (Mansour et al., 1986b). In addition, the binding of putative $\kappa$ opiates was assessed in membranes from guinea pig cerebellum.

\section{Materials and methods}

$\left[{ }^{3} \mathrm{H}\right]\left[\mathrm{D}-\mathrm{Pen}^{2}, \mathrm{D}-\mathrm{Pen}^{5}\right]$ enkephalin $(43 \mathrm{Ci} / \mathrm{mmol})$ and $\left[{ }^{3} \mathrm{H}\right] \mathrm{U} 69,593(42 \mathrm{Ci} / \mathrm{mmol})$ were purchased from New England Nuclear Corporation, and $\left[{ }^{3} \mathrm{H}\right]$ sufentanil $(13.1 \mathrm{Ci} / \mathrm{mmol})$ was obtained from Janssen Pharmaceuticals. Tyr-D-Ala-Gly-(Me) Phe-Gly-ol was bought from Peninsula Laboratories, [D-Ser ${ }^{2}$, Leu $^{5}$ ]enkephalin-Thr ${ }^{6}$ from Cambridge Research Biochemicals, and U69.593 from the Upjohn Company. The other unlabeled opiates were obtained through the Opioid Basic Research Center at the University of Michigan. The peptidase inhibitors bestatin and L-leucyl-leucine were purchased from Sigma Chemical Company, captopril from Squibb and thiorphan from Cambridge Research Biochemicals. The other biochemicals were obtained from Sigma. The chemical purity of all radiolabeled compounds was listed by the manufacturer as higher than $96 \%$. This claim was confirmed in our laboratory by thin-layer chromatography in two different solvent systems recommended by the manufacturer. These determinations of purity were carried out at regular intervals throughout the study.

Membranes from rat cerebrum. rhesus monkey cortex, and guinea pig cerebellum were prepared previously (Fischel and Medzihradsky, 1981; Medzihradsky et al., 1984). Briefly, the dissected tissue was washed in $50 \mathrm{mM}$ Tris- $\mathrm{HCl}, \mathrm{pH} 7.4$, and disrupted for $1 \mathrm{~min}$ in 100 volumes of the ice-cold buffer, using a Polytron homogenizer, model PT-10, at power output 6.5. The homogenate was centrifuged at $20000 \times g$ for $15 \mathrm{~min}$ in the cold, and the obtained pellet resuspended with the original amount of buffer using a Dounce all-glass homogenizer. Aliquots of this suspension, sufficient for experiments on one given day, were frozen at $-70^{\circ} \mathrm{C}$. Prior to its use, the frozen suspension was quickly thawed, dispersed in a Dounce homogenizer and kept on ice. The protein concentration of the membrane suspensions was approximately $0.6 \mathrm{mg} / \mathrm{ml}$ as determined by the method of Lowry et al. (1951), using bovine serum albumin as standard.

The medium of the binding assay, in $8 \mathrm{ml}$ polypropylene tubes, consisted of $400 \mu \mathrm{l}$ membrane suspension (representing the linear range of 
protein dependence as shown in fig. 1C), $50 \mu \mathrm{l}$ of $50 \mathrm{mM}$ Tris- $\mathrm{HCl}, \mathrm{pH} 7.4$, or $\mathrm{NaCl}$ solution to give a final concentration of $150 \mathrm{mM}$ sodium, $50 \mu \mathrm{l}$ of tested compound solution or water (for maximal binding), and $25 \mu 1$ of radiolabeled opiate at the concentrations shown (table 1). Specific binding of the radioligand was defined as the difference between binding in the absence and presence of an appropriate excess of the corresponding unlabeled opiate (fig. 1A, table 1). Constant $\mathrm{pH}$ during the incubation was ascertained. After incubation at $25^{\circ} \mathrm{C}$ to reach binding equilibrium (fig. 1B), the samples were filtered through glass fiber disks (Whatman GF-C) which were initially washed in water and then treated on a filter assembly with water saturated with $\mathrm{N}$-amyl alcohol (Medzihradsky, 1976). The filtered samples were quickly washed with ice-cold $50 \mathrm{mM}$ Tris$\mathrm{HCl}, \mathrm{pH} \mathrm{7.4}$, and placed into polyethylene counting vials. After the addition of $1 \mathrm{ml}$ of absolute ethanol and $10 \mathrm{ml}$ xylene-dioxane-naphtalenebased scintillation fluid, the radioactivity of the samples was determined by liquid scintillation counting. The average counting efficiency, determined by $\left[{ }^{3} \mathrm{H}\right] \mathrm{H}_{2} \mathrm{O}$, was $54 \%$. The experiments with opioid peptides were carried out both in the absence and presence of peptidase inhibitors: 10 $\mu \mathrm{M}$ bestatin, $0.3 \mu \mathrm{M}$ thiorphan, $10 \mu \mathrm{M}$ captopril and $2 \mathrm{mM}$ L-leucyl-leucine (Corbett et al., 1984).
The affinity of the investigated ligands in binding to opioid receptor was expressed as the concentration that inhibited $50 \%$ of maximal binding of a given radiolabeled ligand $\left(\mathrm{EC}_{50}\right)$. The $\mathrm{EC}_{50}$ value was determined by linear regression from plots relating inhibition of specific binding in probit units (Goldstein, 1974) to the log of five different ligand concentrations (fig. 2). The correlation coefficient of the log-probit plot $\left(\mathrm{r}^{2}\right)$ was higher than 0.98 in all cases. Standard deviations, characteristic for each of the three established assays, are listed in tables 2 and 3. Binding selectivity (selectivity index) was expressed as the ratio of $\mathrm{EC}_{50}$ values of a compound in inhibiting the specific binding of two selective radiolabeled ligands, e.g., $\left[{ }^{3} \mathrm{H}\right]$ sufentanil and $\left[{ }^{3} \mathrm{H}\right]\left[\mathrm{D}-\mathrm{Pen}^{2}, \mathrm{D}\right.$ Pen ${ }^{5}$ ]enkephalin.

\section{Results}

In the course of developing the three binding assays, several factors which influence ligand-receptor interaction were considered. The radiolabeled ligands were employed at concentrations (table 1) lower than the $\mathrm{EC}_{50}$ values displayed by their unlabeled forms in inhibiting corresponding radioligand binding (tables 2 and 3). As the concentration of radioligand increases relative to

TABLE 1

Experimental conditions for the opioid receptor binding assays. The experimental procedure is described under Materials and methods.

\begin{tabular}{|c|c|c|c|c|c|c|c|c|}
\hline \multirow[t]{2}{*}{ Radioligand } & \multirow{2}{*}{$\begin{array}{l}\text { Radioligand } \\
\text { concentration } \\
(\mathrm{nM})\end{array}$} & \multirow{2}{*}{$\begin{array}{l}\mathrm{NaCl} \\
(150 \mu \mathrm{M})\end{array}$} & \multirow{2}{*}{$\begin{array}{l}\text { Equili- } \\
\text { brium } \\
\text { reached } \\
\text { (min) }\end{array}$} & \multicolumn{2}{|l|}{ Membranes } & \multirow{2}{*}{$\begin{array}{l}\text { Displacing } \\
\text { unlabeled } \\
\text { ligand } \\
(\mu \mathrm{M})\end{array}$} & \multicolumn{2}{|c|}{ Specific binding } \\
\hline & & & & Source & $\begin{array}{l}\text { Protein } \\
(\mu \mathrm{g} / \text { assay })\end{array}$ & & $\begin{array}{l}\text { (fmol } / \mathrm{mg} \\
\text { protein) }\end{array}$ & $\begin{array}{l}\text { (\% of } \\
\text { total } \\
\text { binding) }\end{array}$ \\
\hline$\left[{ }^{3} \mathrm{H}\right]$ Sufentanil & 0.5 & + & 50 & Rat & 516 & 0.4 & 54 & 82 \\
\hline$\left[{ }^{3} \mathrm{H}\right]$ Sufentanil & 0.5 & - & 50 & Rat & 387 & 0.4 & 72 & 81 \\
\hline$\left[{ }^{3} \mathrm{H}\right]\left[\mathrm{D}-\mathrm{Pen}^{2}, \mathrm{D}-\mathrm{Pen}^{5}\right]$ enkephalin & 1.5 & + & 60 & Rat & 516 & 5.0 & 10 & 67 \\
\hline$\left[{ }^{3} \mathrm{H}\right]\left[\mathrm{D}-\mathrm{Pen}^{2}, \mathrm{D}-\mathrm{Pen}^{5}\right]$ enkephalin & 1.5 & - & 80 & Rat & 387 & 5.0 & 14 & 68 \\
\hline$\left[{ }^{3} \mathrm{H}\right]$ Sufentanil & 0.5 & + & 50 & Monkey & 164 & 0.4 & 45 & 56 \\
\hline$\left[{ }^{3} \mathrm{H}\right]$ Sufentanil & 0.5 & - & 70 & Monkey & 164 & 0.4 & 71 & 69 \\
\hline$\left[{ }^{3} \mathrm{H}\right]\left[\mathrm{D}-\mathrm{Pen}^{2}, \mathrm{D}-\mathrm{Pen}^{5}\right]$ enkephalin & 1.5 & + & 60 & Monkey & 164 & 5.0 & 32 & 69 \\
\hline$\left[{ }^{3} \mathrm{H}\right]\left[\mathrm{D}-\mathrm{Pen}^{2}, \mathrm{D}-\mathrm{Pen}^{5}\right]$ enkephalin & 1.5 & - & 70 & Monkey & 164 & 5.0 & 43 & 72 \\
\hline$\left[{ }^{3} \mathbf{H}\right] \mathrm{U} 69,593$ & 1.5 & - & 40 & Monkey & 20 & 2.0 & 57 & 40 \\
\hline$\left[{ }^{3} \mathrm{H}\right] \mathrm{U} 69,593$ & 1.5 & + & 40 & Guinea pig & 16 & 2.0 & 134 & 62 \\
\hline$\left[{ }^{3} \mathrm{H}\right] \mathrm{U} 69,593$ & 1.5 & - & 40 & Guinea pig & 16 & 2.0 & 123 & 62 \\
\hline
\end{tabular}


TABLE 2

Inhibition of radiolabeled sufentanil and [D-Pen $\left.{ }^{2}, \mathrm{D}-\mathrm{Pen}^{5}\right]$ enkephalin binding in rat and monkey brain. In membranes from rat cerebrum and monkey brain cortex, the inhibition of specific equilibrium binding of $0.5 \mathrm{nM}\left[{ }^{3} \mathrm{H}\right]$ sufentanil or $1.5 \mathrm{nM}\left[{ }^{3} \mathrm{H}\right][\mathrm{D}$ $\mathrm{Pen}^{2}, \mathrm{D}-\mathrm{Pen}^{5}$ ]enkephalin by five different concentrations of the listed compounds was investigated in the presence and absence of 150 $\mathrm{mM} \mathrm{NaCl}$. The $\mathrm{EC}_{50}$ values were determined by linear regression analysis as described under Materials and methods. All regression coefficients $\left(\mathrm{r}^{2}\right)$ were higher than 0.98 . The selectivity index was obtained by dividing the $\mathrm{EC}_{50}$ values of a compound in inhibiting the binding of $\left[{ }^{3} \mathrm{H}\right]$ sufentanil and $\left[{ }^{3} \mathrm{H}\right]\left[\mathrm{D}-\mathrm{Pen}^{2}, \mathrm{D}-\mathrm{Pen}^{5}\right]$ enkephalin, respectively. For compounds with both $\mathrm{EC}_{50} \mathrm{~S}$ in the $\mu \mathrm{M}$ range (U50,488, U69,593), the selectivity indices are not listed (n.1.). All experiments were carried out in duplicate. Listed are either mean values and standard deviations of experiments repeated more than three times, or averages of two experiments with less than $10 \%$ difference between the respective $\mathrm{EC}_{50}$ values.

\begin{tabular}{|c|c|c|c|c|c|}
\hline \multirow[t]{3}{*}{ Compound } & \multicolumn{2}{|l|}{$\left[{ }^{3} \mathrm{H}\right]$ Sufentanil } & \multicolumn{3}{|c|}{$\left[{ }^{3} \mathrm{H}\right]\left[\mathrm{D}-\mathrm{Pen}^{2}, \mathrm{D}-\mathrm{Pen}^{5}\right]$ enkephalin } \\
\hline & \multirow{2}{*}{$\begin{array}{l}\mathrm{EC}_{50}(\mathrm{nM}) \\
(+\mathrm{NaCl})\end{array}$} & \multirow{2}{*}{$\frac{\mathrm{EC}_{50}(+\mathrm{Na})}{\mathrm{EC}_{50}(-\mathrm{Na})}$} & \multirow{2}{*}{$\begin{array}{l}\mathrm{EC}_{50}(\mathrm{nM}) \\
(+\mathrm{NaCl})\end{array}$} & \multirow{2}{*}{$\frac{\mathrm{EC}_{50}(+\mathrm{Na})}{\mathrm{EC}_{50}(-\mathrm{Na})}$} & \multirow{2}{*}{$\begin{array}{l}\text { Selectivity } \\
\text { index } \\
(\mu / \delta)\end{array}$} \\
\hline & & & & & \\
\hline \multicolumn{6}{|l|}{ Rat cerebrum } \\
\hline Tyr-D-Ala-Gly-(Me)Phe-Gly-ol & 13.2 & 1.36 & 690 & 2.16 & 0.02 \\
\hline Sufentanil & $1.25 \pm 0.08$ & 1.38 & 45.0 & 2.47 & 0.03 \\
\hline Morphine & 31.4 & 1.76 & 422 & 2.74 & 0.07 \\
\hline$\beta$-FNA & 6.99 & 0.61 & 43.9 & 0.82 & 0.16 \\
\hline$\beta-C N A$ & 1.29 & 0.74 & 7.48 & 1.03 & 0.17 \\
\hline Naloxone & 6.37 & 0.49 & 14.3 & 0.52 & 0.44 \\
\hline Etorphine & 0.60 & 2.16 & 1.13 & 1.56 & 0.54 \\
\hline Buprenorphine & 1.07 & 0.73 & 1.12 & 0.95 & 0.96 \\
\hline Bremazocine & 1.79 & 0.69 & 1.12 & 1.48 & 1.60 \\
\hline Superfit & 576 & 1.88 & 16.5 & 2.24 & 34.9 \\
\hline$\left[\mathrm{D}-\mathrm{Ser}^{2}{ }^{2}\right.$ Leu $\left.^{5}\right]$ enkephalin-Thr ${ }^{6}$ & $121 \pm 16$ & 0.68 & $1.05 \pm 0.16$ & 0.68 & 115 \\
\hline ICI-174,864 & $58900 \pm 9700$ & 0.25 & 59.0 & 0.08 & 998 \\
\hline$\left[\mathrm{D}-\mathrm{Pen}^{2}, \mathrm{D}-\mathrm{Pen}^{5}\right]$ enkephalin & $7720 \pm 320$ & 0.76 & $6.44 \pm 0.67$ & 0.98 & 1200 \\
\hline U 50,488 & 7230 & - & 13100 & - & n.l. \\
\hline U69593 & 38000 & - & 13400 & - & n.l. \\
\hline \multicolumn{6}{|l|}{ Monkey cortex } \\
\hline Sufentanil & $1.18 \pm 0.35$ & 1.96 & $81.1 \pm 15.0$ & 2.16 & 0.01 \\
\hline$\left[\mathrm{D}-\mathrm{Pen}^{2}, \mathrm{D}-\mathrm{Pen}^{5}\right]$ enkephalin & $18900 \pm 2700$ & 1.20 & $4.21 \pm 0.47$ & 0.81 & 4490 \\
\hline U69,593 & 10700 & - & 17000 & - & n.1. \\
\hline
\end{tabular}

its $\mathrm{K}_{\mathrm{d}}$, the deviation of the obtained $\mathrm{EC}_{50}$ values from the actual $K_{i}$ increases (e.g., Bennett, 1978). In rat brain membranes, the $\mathrm{K}_{\mathrm{d}}$ s for $\left[{ }^{3} \mathrm{H}\right]$ sufentanil and $\left[{ }^{3} \mathrm{H}\right]\left[\mathrm{D}-\mathrm{Pen}^{2}, \mathrm{D}-\mathrm{Pen}^{5}\right]$ enkephalin binding were $0.9 \mathrm{nM}$ and $4.2 \mathrm{nM}$, respectively (Remmers and Medzihradsky, 1987). In previous reports, the $\mathrm{K}_{\mathrm{d}}$ values for $\left[{ }^{3} \mathrm{H}\right]$ sufentanil binding in membranes from rat forebrain (Leysen et al., 1983), and for $\left[{ }^{3} \mathrm{H}\right]\left[\right.$ D-Pen ${ }^{2}$, D-Pen $\left.{ }^{5}\right]$ enkephalin binding in slidemounted sections of rat brain (Mansour et al., 1986a) were $0.3 \mathrm{nM}$ and $8.0 \mathrm{nM}$, respectively. In membranes from rat brain and guinea pig cerebellum, the corresponding $\mathrm{K}_{d} \mathrm{~s}$ for $\left[{ }^{3} \mathrm{H}\right] \mathrm{U} 69,593$ binding (without $\mathrm{NaCl}$ ) were $4 \mathrm{nM}$ and $0.9 \mathrm{nM}$ (Lahti et al., 1985). Thus, in rat brain membranes (table 2), the approximate ratios of $\mathrm{K}_{\mathrm{d}}$ to employed radioligand concentration were $1.8,2.8$ and 2.6 for $\left[{ }^{3} \mathrm{H}\right]$ sufentanil, $\left[{ }^{3} \mathrm{H}\right]\left[\mathrm{D}-\mathrm{Pen}^{2}, \mathrm{D}-\mathrm{Pen}^{5}\right] \mathrm{en}$ kephalin and $\left[{ }^{3} \mathrm{H}\right] \mathrm{U} 69,593$, respectively.

As illustrated for $\left[{ }^{3} \mathrm{H}\right]$ sufentanil (fig. 1), the concentration of unlabeled ligand employed to determine specific binding of the radioligand, and the dependence on time and protein of specific ligand binding at equilibrium were assessed for each of the three binding assays (table 1). The concentrations of unlabeled opiates (table 1) reflect maximal displacement of the respective radioligand (fig. 1A). Also confirmed was the unaltered radiochemical purity of the radioligands throughout the study. Particular emphasis was 

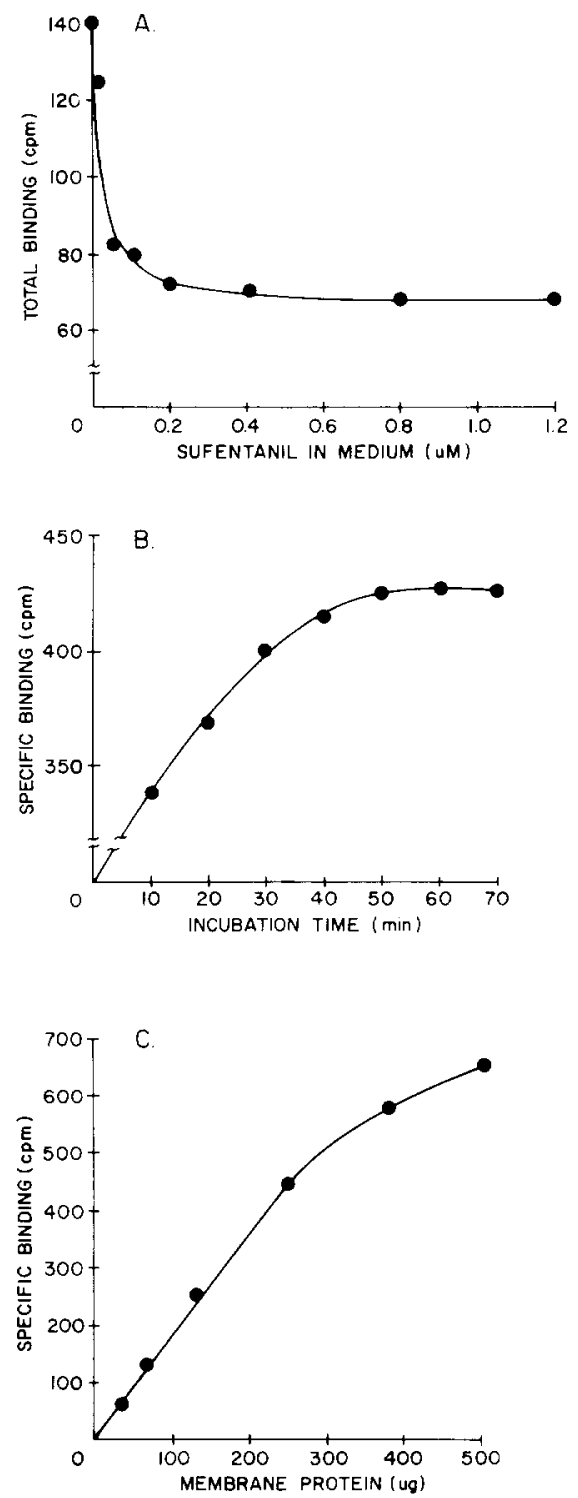

Fig. 1. Characteristics of $\left[{ }^{3} \mathrm{H}\right]$ sufentanil binding in rat brain. In suspensions of rat cerebral membranes the binding of $0.5 \mathrm{nM}$ $\left[{ }^{3} \mathrm{H}\right]$ sufentanil in the presence of increasing concentrations of unlabeled sufentanil was determined following incubation for $50 \mathrm{~min}$ at $25^{\circ} \mathrm{C}$ (panel A). Specific binding was defined as the difference between $\left[{ }^{3} \mathrm{H}\right]$ sufentanil bound in the absence of unlabeled sufentanil and in the presence of sufficient sufentanil to cause maximal inhibition of the radiolabeled ligand. The specific binding of $0.5 \mathrm{nM}\left[{ }^{3} \mathrm{H}\right]$ sufentanil was determined after various times of incubation at $25^{\circ} \mathrm{C}$ (panel $\mathrm{B}$ ), and in the presence of increasing concentrations of membrane protein following incubation for $50 \mathrm{~min}$ at $25^{\circ} \mathrm{C}$ (panel C). Shown are averages of two experiments, run in duplicate. placed on measuring ligand-receptor interactions under well defined equilibrium conditions: constant temperature of the samples was maintained throughout the incubation and filtering. Control experiments showed that placing the tubes in ice before filtering decreased the temperature of the assay suspension to $2^{\circ} \mathrm{C}$ in $10 \mathrm{~min}$, and below $1^{\circ} \mathrm{C}$ in 25 min. During that time, specific binding of $\left[{ }^{3} \mathrm{H}\right]$ sufentanil decreased by 17 and $29 \%$, respectively (data not shown). The lack of peptidase action during the experiments was ascertained by the use of the enzyme inhibitors bestatin, captopril and thiorphan (and L-leucyl-leucine) at concentrations as described (Corbett et al., 1984).

Under the employed experimental conditions (table 1), the extent specific binding and the ratio of total to specific binding of $\left[{ }^{3} \mathrm{H}\right]$ sufentanil and $\left[{ }^{3} \mathrm{H}\right]\left[\mathrm{D}-\mathrm{Pen}^{2}, \mathrm{D}-\mathrm{Pen}^{5}\right]$ enkephalin in rat and monkey brain membranes were favorable for use in routinely applicable binding assays. However this was not the case for $\left[{ }^{3} \mathrm{H}\right] \mathrm{U} 69,593$ : at 1-2 $\mathrm{nM}$ concentrations the extent of specific binding was marginal and resulted in a non-linear protein dependence above $5 \mu \mathrm{g}$ membrane protein, corresponding to approximately $50 \mathrm{cpm}$. Moreover, in monkey cortex the binding assay was implemented only in the absence of $\mathrm{NaCl}$ in order to improve the statistical significance of the data: even without sodium the specific binding of $\left[{ }^{3} \mathrm{H}\right] \mathrm{U} 69,593$ represented only $44 \%$ of total binding (table 1). The results obtained with monkey brain were substantiated by the data on $\left[{ }^{3} \mathrm{H}\right] \mathrm{U} 69,593$ binding in membranes from guinea pig cerebellum, a tissue containing predominantly $\kappa$ opioid receptors (Robson et al., 1984). In these membranes, specific binding amounted to $62 \%$ of total binding (table 3 ), and $\mathrm{B}_{\max }$ was similar to the value reported for homogenates of guinea pig brain (Lahti et al., 1985). The latter publication contained no information on the extent specific binding.

Whereas in rat brain membranes the inhibition of $\left[{ }^{3} \mathrm{H}\right]$ sufentanil (fig. 2) and $\left[{ }^{3} \mathrm{H}\right]\left[\mathrm{D}-\mathrm{Pen}^{2}, \mathrm{D}\right.$ Pen $^{5}$ ]enkephalin binding by various opioids, including alkaloids, peptides, agonists, mixed agonists and antagonists was determined (table 2), the restricted supply of monkey brain membranes limited our investigation in this tissue to the three 


\section{TABLE 3}

Inhibition of radiolabeled U69,593 binding in monkey and guinea pig brain. In membranes from monkey brain cortex and guinea pig cerebellum, the inhibition of the specific equilibrium binding of $1.5 \mathrm{nM}\left[{ }^{3} \mathrm{H}\right] \mathrm{U} 69,593$ by five concentrations of the listed opiates was investigated in the absence of $\mathrm{NaCl}$. The $\mathrm{EC}_{50}$ values were determined by linear regression from log concentration-probit plots of the data as described under Materials and methods. All regression coefficients were higher than 0.96 . The selectivity indices were obtained by dividing the $\mathrm{EC}_{50}$ values of a compound in inhibiting the binding of $\left[{ }^{3} \mathrm{H}\right]$ sufentanil and $\left[{ }^{3} \mathrm{H}\right] \mathrm{U} 69,593(\mu / \kappa$ index) or the binding of $\left[{ }^{3} \mathrm{H}\right]\left[\right.$ D-Pen ${ }^{2}$,D-Pen $\left.{ }^{5}\right]$ enkephalin and $\left[{ }^{3} \mathrm{H}\right] \mathrm{U} 69,593(\delta / \kappa$ index $)$, respectively. Shown are either mean values and standard deviations of experiments repeated more than three times, or averages of two experiments, all carried out in duplicate.

\begin{tabular}{llll}
\hline Compound & $\begin{array}{l}\mathrm{EC}_{50} \\
(\mathrm{nM})\end{array}$ & \multicolumn{2}{c}{ Selectivity index } \\
\cline { 3 - 4 } & & $(\mu / \kappa)$ & $(\delta / \kappa)$ \\
\hline Monkey cortex & $8.41 \pm 2.08$ & 2830 & 765 \\
Sufentanil & $>10000$ & $<10^{-4}$ & $<10^{-3}$ \\
[D-Pen ${ }^{2}$,D-Pen $\left.{ }^{5}\right]$ enkephalin & $>10000$ & 1.01 & $<10^{-4}$ \\
Guinea pig cerebellum & & & \\
U69,593 & $3.71 \pm 0.35$ & - & - \\
U50,488 & $2.08 \pm 0.12$ & - & - \\
Bremazocine & 0.64 & - & - \\
Sufentanil & 998 & - & - \\
[D-Pen ${ }^{2}$, D-Pen ${ }^{5}$ ]enkephalin & $>40000$ & - & - \\
\hline
\end{tabular}

opiates used as radiolabeled primary ligands (tables 2 and 3). In membranes from guinea pig cerebellum the experiments focused on the binding of putative $\kappa$ opioids, but also included, as a control, the assessment of the highly selective $\mu$ and $\delta$ opiates sufentanil and [D-Pen ${ }^{2}$, D-Pen ${ }^{5}$ enkephalin (table 3).

In presenting the data we gave preference to the $\mathrm{EC}_{50}$ values obtained in the presence of sodium (table 2), a condition that reflects, in part, the extracellular environment of the receptor. The effect of $\mathrm{NaCl}$ on $\mu$ and $\delta$ ligand binding was similar in rat and monkey membranes. Relative to the assay with sodium, in the absence of the ion the extent of specific binding of the agonist $\left[{ }^{3} \mathrm{H}\right]$ sufentanil increased by 22 and $25 \%$ in rat and monkey membranes, respectively. The corresponding values for $\left[{ }^{3} \mathrm{H}\right]\left[\mathrm{D}-\mathrm{Pen}^{2}, \mathrm{D}-\mathrm{Pen}^{5}\right]$ enkephalin were 25 and $28 \%$ (table 1). Sodium downshifted the $\mathrm{EC}_{50}$ values of the $\mu$ agonists sufentanil,

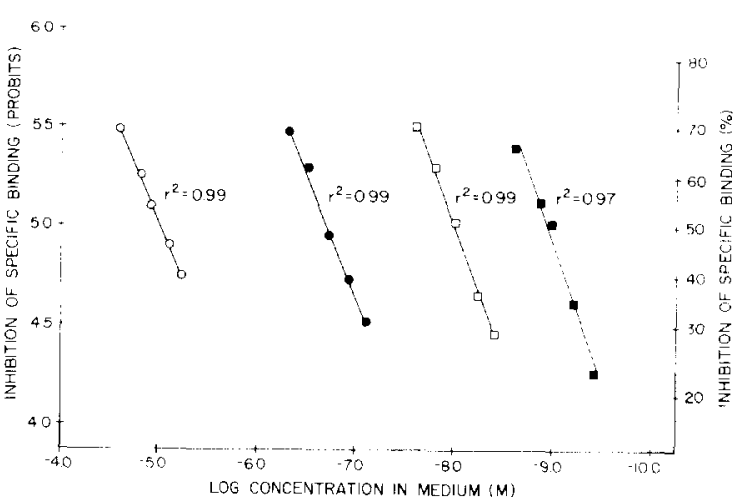

Fig. 2. Inhibition of specific $\left[{ }^{3} \mathrm{H}\right]$ sufentanil binding in rat brain. Rat cerebral membranes were incubated with $0.5 \mathrm{nM}$ $\left[{ }^{3} \mathrm{H}\right]$ sufentanil for $40 \mathrm{~min}$ at $25^{\circ} \mathrm{C}$ in the absence of sodium with sufentanil (E), Tyr-D-Ala-Gly-(Me)Phe-Gly-ol (D), (D$\mathrm{Ser}^{2}$, Leu $^{5}$ )enkephalin-Thr ${ }^{6}(\bullet)$, and (D-Pen ${ }^{2}, \mathrm{D}-\mathrm{Pen}^{5}$ ) enkephalin $(O)$, at concentrations as indicated. Plotted is the extent inhibition (in percent and probit units) of maximal specific binding of $\left[{ }^{3} \mathrm{H}\right]$ sufentanil against the $\log$ concentration of the tested opiates. The log-probit plots were obtained from linear regression analyses yielding the correlation coefficients depicted in the figure. Shown are results of representative experiments carried out in duplicate and repeated three to four times.

morphine and Tyr-D-Ala-Gly-(Me)Phe-Gly-ol more than those of the $\delta$ agonists [D-Pen ${ }^{2}, \mathrm{D}-$ $\left.\mathrm{Pen}^{5}\right]$ enkephalin and $\left[\mathrm{D}-\mathrm{Ser}^{2}, \mathrm{Leu}^{5}\right.$ ]enkephalin (tables 1 and 2). The specific binding of the $\kappa$ agonist $\left[{ }^{3} \mathrm{H}\right] \mathrm{U} 69,593$ was also characterized by a relatively small sodium response (tables 1 and 3 ): the $\mathrm{EC}_{50}$ of its inhibition by $U 69,593$ in the presence of 150 $\mathrm{mM} \mathrm{NaCl}$ was $4.69 \mathrm{nM}$. It is of interest that the $\mathrm{EC}_{50} \mathrm{~s}$ of both naloxone and the $\delta$ selective antagonist peptide ICI 174,864 (Cotton et al., 1984) were strongly affected by sodium (table 2 ).

Relative binding selectivity of a tested compound was expressed as the ratio of its $\mathrm{EC}_{50} \mathrm{~s}$ in inhibiting the binding (fig. 2) of two selective radioligands, e.g. $\left[{ }^{3} \mathrm{H}\right]$ sufentanil and $\left[{ }^{3} \mathrm{H}\right][\mathrm{D}$ Pen $\left.^{2}, \mathrm{D}-\mathrm{Pen}^{5}\right]$ enkephalin (selectivity index: $\mu / \delta$ ). The selectivity of a compound was independent of its binding affinity, e.g., Tyr-D-Ala-Gly-(Me)PheGly-ol and sufentanil showed similar $\mu$ selectivity, although their binding affinities at the $\mu$ receptor were markedly different. In rat membranes the selectivity indices ranged from 0.02 and 0.03 for Tyr-D-Ala-Gly-(Me)Phe-Gly-ol and sufentanil, the most $\mu$ selective compounds, to 1200 for [D- 
Pen $^{2}$, D-Pen ${ }^{5}$ enkephalin, representing the highest $\delta$ selectivity (table 2 ). Whereas selectivity indices below 0.5 and above 1.6 reflected preferential recognition at $\mu$ and $\delta$ sites, respectively, values between these margins identified nonselective opiates such as etorphine, buprenorphine and bremazocine. Among the antagonists, ICI 174,864 exhibited high $\delta$ selectivity with an index of 998 , while naloxone was relatively nonselective. Of the three 'irreversible' opioid ligands, superfit (Smith et al., 1985; Clark and Medzihradsky, 1986) had considerable $\delta$ selectivity, while $\beta$-funaltrexamine ( $\beta$-FNA) and $\beta$-chlornaltrexamine $(\beta$-CNA) (Ward et al., 1982) showed preference toward $\mu$ sites. In monkey cortical membranes the selectivities of sufentanil and [D-Pen ${ }^{2}$, D-Pen ${ }^{5}$ ]enkephalin were even more pronounced than in rat brain (table 2).

While the putative $\kappa$ opiates U50,488 (Von Voigtlander et al., 1983) and U69,593 (Lahti et al., 1985) were not recognized at $\mu$ and $\delta$ sites in rat brain (table 2), they inhibited the binding of $\left[{ }^{3} \mathrm{H}\right] \mathrm{U} 69,593$ with high potency in guinea pig cerebellum or monkey cortex (table 3 ). Bremazocine inhibited the binding of $\left[{ }^{3} \mathrm{H}\right] \mathrm{U} 69,593$ in guinea pig cerebellum with a low $\mathrm{EC}_{50}$, but it also bound with high affinity to $\mu$ and $\delta$ sites in rat brain. Sufentanil and [D-Pen $\left.{ }^{2}-\mathrm{D}-\mathrm{Pen}^{5}\right]$ enkephalin were rejected from sites labeled by $\left[{ }^{3} \mathrm{H}\right] \mathrm{U} 69,593$ in monkey brain and guinea pig cerebellum (table 3 ).

\section{Discussion}

The availability of the highly selective $\mu, \delta$ and $\kappa$ opiates sufentanil (Leysen et al., 1983), [D$\mathrm{Pen}^{2}, \mathrm{D}-\mathrm{Pen}^{5}$ ]enkephalin (Mosberg et al., 1983) and U69,593 (Lahti et al., 1985) as radiolabeled ligands enabled us to investigate the selectivity of various opiates in direct binding assays without the use of protective ligands (e.g., Gillan and Kosterlitz, 1982) or initial alkylation (James and Goldstein, 1984), approaches which carry the risk of incomplete receptor protection or receptor alteration. It is of interest that insufficient ligand binding following protective receptor alkylation with $\beta$-CNA prevented the assessment of opioid binding selectivity in an artificial extracellular medium (James and Goldstein, 1984). In our work, selective unlabeled opiates such as Tyr-D-Ala-Gly-(Me)PheGly-ol, ICI 174,864 and U50,488 served as pertinent reference compounds in evaluating the binding of other opiates to the sites labeled by the three radioligands. The results on the inhibition of radioligand binding were purposefully presented as $\mathrm{EC}_{50} \mathrm{~s}$ rather than the, theoretically more accurate, $\mathrm{K}_{\mathrm{i}}$ values. The approach taken simplifies the comparison with pertinent data on the receptor binding of novel opiates, frequently presented as $\mathrm{EC}_{50}$ s (e.g., Woods et al., 1979; Woods et al., 1987). Furthermore, the binding assays in the present work were carried out under experimental conditions which minimize the difference between the obtained $\mathrm{EC}_{50}$ values and the corresponding $\mathrm{K}_{\mathrm{i}} \mathrm{s}$ (fig. 1, table 1), parameters linked by the relationship $\mathrm{K}_{\mathrm{i}}=\mathrm{EC}_{50} /\left[1+\left(\mathrm{L} / \mathrm{K}_{\mathrm{d}}\right)\right]$ (Cheng and Prusoff, 1973).

Our original goal was to compare the binding selectivity of distinct opiates in membranes from rat and monkey brain. However, the limited density of binding sites for $\left[{ }^{3} \mathrm{H}\right] \mathrm{U} 69,593$ in rat brain membranes made this tissue unsuitable for the routine assessment of $\kappa$ ligand binding. To support the data obtained with monkey membranes, the study was expanded to include guinea pig cerebellum, a tissue containing predominantly $\kappa$ opioid receptors as reflected in ligand binding (Robson et al., 1984) and receptor-G-protein coupling (Clark et al., 1986). Our selection of monkey brain cortex was guided by its content of $\mu, \delta$ and $\kappa$ opioid receptors (Mansour et al., 1986b) and, considering possible application in routine assays, by the large quantity of this tissue. Indeed, according to the results of this study, membranes from monkey cortex appear to be an interesting alternative to rat brain membranes in investigating the interaction of opioid ligands with multiple opioid receptors (Medzihradsky, 1987).

The present investigation confirmed the differential sensitivity of $\mu$ and $\delta$ ligand binding towards extracellular concentrations of $\mathrm{NaCl}$ (Paterson et al., 1986). This difference was observed both in rat and monkey brain membranes. We have previously described the resolution of $\mu$ and $\kappa$ receptor binding on the basis of smaller responses of $\kappa$ agonists to sodium 
(Medzihradsky et al., 1984), a property displayed in this study by $\left[{ }^{3} \mathrm{H}\right] \mathrm{U} 69,593$ binding as well.

The obtained selectivity indices in rat brain clearly identified opiates with high $\mu$ and $\delta$ selectivity. The indices of less selective compounds underlined the necessity to carefully analyze the $\mathrm{EC}_{50} \mathrm{~s}$ used for their computation; e.g. [D-Ser ${ }^{2}$, Leu $^{5}$ ]enkephalin-Thr ${ }^{6}$, a putative $\delta$ agonist (David et al., 1982), had a relatively low selectivity index, $\mu / \delta$ of 115 although it inhibited $\left[{ }^{3} \mathrm{H}\right]\left[\mathrm{D}-\mathrm{Pen}^{2}, \mathrm{D}\right.$ $\mathrm{Pen}^{5}$ ]enkephalin binding with an $\mathrm{EC}_{50}$ of 1.05 , a potency five times higher than that of $\left[\mathrm{D}-\mathrm{Pen}^{2}, \mathrm{D}\right.$ Pen $\left.^{5}\right]$ enkephalin. However, [D-Ser ${ }^{2}$, Leu $\left.^{5}\right]$ enkephalin-Thr ${ }^{6}$ was recognized at $\mu$ sites with a 64fold higher affinity than [D-Pen ${ }^{2}, \mathrm{D}-\mathrm{Pen}^{5}$ ] enkephalin (table 2). Considering the binding profile of the putative $\kappa$ agonist bremazocine, there seems to be little advantage of its use to label $\kappa$ sites over that etorphine, a recognized nonselective opiate. In contrast, the true $\kappa$ ligands U50,488 and U69,593, showed rejection by the $\mu$ and $\delta$ receptors.

The binding assay with $\left[{ }^{3} \mathrm{H}\right] \mathrm{U} 69,593$ as the primary ligand now allows the accurate assessment of ligand interaction with the $\kappa$ opioid receptor. The binding profile of putative $\kappa$ opiates in monkey brain cortex and guinea pig cerebellum confirmed the superior $\kappa$ selectivity of U50,488 and U69,593. In both membrane preparations, sufentanil and [D-Pen ${ }^{2}$, D-Pen ${ }^{5}$ ]enkephalin, but not bremazocine, were excluded from sites labeled by $\left[{ }^{3} \mathrm{H}\right] \mathrm{U69}, 593$. In membranes from rat cerebrum the binding assay was not established due to the low density of $\kappa$ sites. In that respect, it is of interest that in rat brain slices mounted for autoradiography, the $\mathrm{EC}_{50}$ for $\mathrm{U} 50,488$ was 179 -fold higher than that of bremazocine in displacing $\left[{ }^{3} \mathrm{H}\right]$ bremazocine (Mansour et al., 1986a).

Notwithstanding the inclusion in our study of novel opioid ligands in tritiated or unlabeled form, the findings of this work are in general agreement with the selectivity of opiates described in rat brain and guinea pig ileum using, in part, ligand protection to counter cross-reactivity of the radiolabeled primary ligands (Gillan and Kosterlitz, 1982; Corbett et al., 1984). Our data also support the ranking of Tyr-D-Ala-Gly-(Me)Phe-Gly-ol and sufentanil, [D-Pen ${ }^{2}$, D-Pen $\left.{ }^{5}\right]$ enkephalin, and
U50,488 as highly selective $\mu, \delta$, and $\kappa$ opiates, respectively, following receptor alkylation in guinea pig brain membranes (James and Goldstein, 1984), although diverging selectivities for the $\delta$ antagonist analogues ICI 174,864 (Cotton et al., 1984) and ICI 154,129 (Shaw et al., 1982) were obtained in the two studies. The binding selectivities described in this paper corraborate those displayed by opioid agonists and antagonists in the course of receptor-mediated stimulation of brain GTPase (Clark and Medzihradsky, 1987). The similarity of results obtained by different methods validates the direct approach applied in this study based on the equilibrium binding of three highly selective radiolabeled ligands. These assays are now being used to guide the synthesis of novel selective opiates (Mosberg et al., 1987). It will be of interest to compare the selectivity profile described here with that obtained by inhibiting the binding of the nonselective ligand $\left[{ }^{3} \mathrm{H}\right]$ etorphine in membranes made specific for a given type of opioid receptor by selective alkylation (Medzihradsky, 1987).

\section{Acknowledgements}

The authors are grateful to Dr. J.H. Woods for many valuable discussions, and would like to thank Ms. B. McLaughlin for excellent assistance in typing the manuscript. This work was supported in part by USPHS Grant DA 00254.

\section{References}

Bennett, J.P., Jr., 1978, Methods in binding studies, in: Neurotransmitter Receptor Binding, eds. H.I. Yamamato, S.J. Enna and M.J. Kuhar (Raven Press, New York) p. 57.

Change, K.-J., E. Hazum and P. Cuatrecasas, 1980, Possible role of distinct morphine and enkephalin receptors in mediating actions of benzomorphan drugs (putative $\kappa$ and $\delta$ agonists), Proc. Natl. Acad. Sci. U.S.A. 77, 4469.

Cheng, Y.-C. and W.H. Prusoff, 1973, Relationship between inhibition constant $\left(\mathrm{K}_{\mathrm{i}}\right)$ and the concentration of inhibitor which causes 50 percent inhibition $\left(\mathrm{IC}_{50}\right)$ of an enzyme reaction, Biochem. Pharmacol. 22, 3099.

Clark, M.J., S.D. Levenson and F. Medzihradsky, 1986, Evidence for coupling of the $\kappa$ opioid receptor to brain GTPase, Life Sci. 39, 1721

Clark, M.J. and F. Medzihradsky, 1986, Spare ligand binding sites in the coupling of opioid receptor to brain GTPase. Res. Mongr., Natl. Inst. Drug Abuse U.S.A. 75, 145. 
Clark, M.J. and F. Medzihradsky, 1987, Coupling of multiple opioid receptors to GTPase following selective receptor alkylation in brain membranes, Neuropharmacology (in press).

Corbett, A.D., M.G.C. Gillan, H.W. Kosterlitz, A.T. McKnight, S.J. Paterson and L.E. Robson, 1984, Selectivities of opioid peptide analogues as agonists and antagonists at the $\delta$-receptor, Br. J. Pharmacol. 83, 271.

Cotton, R., M.B. Giles, L. Miller, J.S. Shaw and T. Times, 1984, ICI 174,864: a highly selective antagonist for the opioid $\delta$ receptor, European J. Pharmacol. 97, 331.

David, M., C. Moisand, J.C. Mennier, J.L. Moreat, G. Gacel and B.P. Roques, 1982, [ $\left.{ }^{3} \mathrm{H}\right]$-Tyr-D-Ser-Gly-Phe-Leu-Thr: a specific probe for the $\delta$-opiate receptor subtype in brain membranes, European J. Pharmacol. 78, 385.

Fischel, S.V. and F. Medzihradsky, 1981, Scatchard analysis of opiate receptor binding, Mol. Pharmacol. 20, 269.

Fischel, S.V. and F. Medzihradsky, 1986, Interaction between ${ }^{3} \mathrm{H}$-ethylketocyclazocine and ${ }^{3} \mathrm{H}$-etorphine and opioid receptors in membranes from rat brain: A kinetic analysis, Neuropharmacology 25, 351.

Garzon, J., P. Sanchez-Blazquez and N.M. Lee, 1984, $\left[{ }^{3}\right.$ H]Ethylketocyclazocine binding to mouse brain membranes: evidence for a $\kappa$ opioid receptor type, J. Pharmacol. Exp. Therap. 231, 33.

Gillan, M.G.C. and H.W. Kosterlitz, 1982, Spectrum of the $\mu$-, $\delta$ - and $\kappa$-binding sites in homogenates of rat brain, $\mathrm{Br} . \mathrm{J}$. Pharmacol. 77, 461.

Goldstein, A., 1974, Principles of Drug Action: The Basis of Pharmacology (J. Wiley \& Sons, New York) p. 380.

Hiller, J.M. and E.J. Simon, 1979, $\left[{ }^{3} \mathrm{H}\right]$ Ethylketocyclazocine binding: lack of evidence for a separate $\kappa$ receptor in the rat CNS, European J. Pharmacol. 60, 389.

James, I.F. and A. Goldstein, 1984, Site-directed alkylation of multiple opioid receptors. I. Binding selectivity, Mol. Pharmacol. 25, 343.

Lahti, R.A., M.M. Mickelson, J.M. McCall and P.F. Von Voigtlander, 1985, $\left[{ }^{3} \mathrm{H}\right] \mathrm{U}-69,584$, a highly selective ligand for the opioid $\kappa$ receptor, European J. Pharmacol. 109, 281.

Leysen, J.E., W. Gommers and C.J.E. Niemegeers, 1983, $\left[{ }^{3} \mathrm{H}\right]$ Sufentanil, a superior ligand for $\mu$-opiate receptors: binding properties and regional distribution in rat brain and spinal cord, European J. Pharmacol. 87, 209.

Lowry, O.H., N.A. Rosebrough, A.L. Farr and R.J. Randall, 1951, Protein measurement with the Folin phenol reagent, J. Biol. Chem. 193, 265.

Mansour, A., M.E. Lewis, H. Khachaturian, H. Akil and S. Watson, 1986a, Pharmacological and anatomical evidence of selective $\mu, \delta$, and $\kappa$ opioid receptor binding in rat brain, Brain Res. 399, 69 .

Mansour, A., M.E. Lewis, H. Khachaturian and S.J. Watson, 1986b, Multiple opioid receptor subtypes in the monkey, Abstr. Ann. Neurosci. Meeting. Washington, D.C., U.S.A. Martin, W.R., C.O. Eades, J.A. Thompson, H. Huppler and
P.E. Gilbert, 1976, The effects of morphine and nalorphine-like drugs in the nondependent and morphinedependent chronic spinal dog, J. Pharmacol. Exp. Ther. $197,517$.

Medzihradsky, F., 1976, Stereospecific binding of etorphine in isolated neural cells and retina, determined by a sensitive microassay, Brain Res. 108, 212.

Medzihradsky, F., 1987, Novel biochemical determinants in the preclinical evaluation of opiates, Res. Monogr. Natl. Inst. Drug Abuse, U.S.A., 76, 349

Medzihradsky, F., P.J. Dahlstrom, J.H. Woods, S.V. Fischel and S.E. Mitsos, 1984, Resolution in the receptor binding of putative $\mu$ and $\kappa$ opiates, Life Sci. 34, 2013.

Mosberg, H.I., R. Hurst, V.J. Hruby, K. Gee, H.I. Yamamura, J.J. Galligan and T.F. Burks, 1983, Bis-pencillamine enkephalins possess highly improved specificity towards $\delta$ opioid receptors, Proc. Natl. Acad. Sci. U.S.A. 80, 5871.

Mosberg, H.I., J.R. Omnaas, M.J. Clark and F. Medzihradsky, 1987, Disulfide- and dithioether-containing cyclic opioids tetrapeptides, Abstr. Tenth Am. Pept. Symp., St. Louis, MO, U.S.A.

Paterson, S.J, L.E. Robson and H.W. Kosterlitz, 1986, Control by cations of opioid binding in guinea pig brain membranes, Proc. Natl. Acad. Sci. U.S.A. 83, 6216.

Remmers, A.E. and F. Medzihradsky, 1987, Modulation of ligand binding to opioid receptors by membrane lipids, $\mathbf{J}$. Neurosci. (in press).

Robson, L.E., R.W. Foote, R. Maurer and H.W. Kosterlitz, 1984 , Opioid binding of the $\kappa$-type in guinea-pig cerebellum, Neuroscience 12, 621.

Shaw, J.S., L. Miller, M.J. Turnbull, J.J. Gormley and J.S. Morley, 1982, Selective antagonists at the opiate $\delta$-receptor, Life Sci. 31, 1259.

Smith, C.B., A.E. Jacobson, T.R. Burke, K.C. Rice and J.H. Woods, 1985, Actions of 'irreversible' $\delta$ opiate receptor agonists on the mouse vas deferens, Fed. Proc. 44, 610.

Takemori, A.E. and P.S. Portoghese, 1985, Affinity labels for opioid receptors, Ann. Rev. Pharmacol. Toxicol. 25, 193.

Von Voigtlander, P.F., R.A. Lahti and J.H. Ludens, 1983, U-50,488: a selective and structurally novel non- $\mu$ ( $\kappa)$ opioid agonist, J. Pharmacol. Exp. Ther. 225, 7.

Ward, S.J., P.S. Portoghese and A.E. Takemori, 1982 , Pharmacological profiles of $\beta$-funaltrexamine $(\beta$-FNA) and $\beta$-chlornaltrexamine ( $\beta$-CNA) on the mouse vas deferens preparation, European J. Pharmacol. 80, 377.

Woods, J.H., C.B. Smith, F. Medzihradsky and H.H. Swain, 1979, Preclinical testing of new analgesic drugs, in: Mechanisms of Pain and Analgesic Compounds, eds. R.F. Beers, Jr. and E.G. Bassett (Raven Press, New York) p. 29.

Woods, J.H., C.B. Smith, F. Medzihradsky, G. Winger and D.E. Gmerek, 1987, Evaluation of new compounds for opioid activity, Res. Monogr. Natl. Inst. Drug Abuse, U.S.A. 76,448 